\title{
LICHENS AS INDICATORS OF AIR POLLUTION IN ŁOMŻA
}

\author{
Anna Matwiejuk, Paulina Chojnowska
}

\begin{abstract}
A. Matwiejuk, P. Chojnowska, Institute of Biology, University of Bialystok, Konstanty Ciołkowski $1 \mathrm{~J}$,
\end{abstract} 15-245 Białystok, Poland, e-mail: matwiej@uwb.edu.pl, pchojnowska@wp.pl

(Received: December 9, 2015. Accepted: March 29, 2016)

\begin{abstract}
AвSTRACт. Research using lichens as bioindicators of air pollution has been conducted in the city of Łomża. The presence of indicator species of epiphytic and epilithic lichens has been analysed. A 4-point lichen scale has been developed for the test area, on the basis of which four lichenoindication zones have been determined. The least favourable conditions for lichen growth have been recorded in the city center. Green areas and open spaces are the areas with the most favourable impact of the urban environment on lichen biota.
\end{abstract}

KEY WORDS: air pollution, biodiversity, lichens, urban environment

\section{INTRODUCTION}

Lichens (lichenized fungi, Fungi lichenisati) are symbiotic organisms, created in most cases by an association of green algae (Chlorophyta) or blue-green algae (Cyanobacteria) and fungi, especially ascomycetes (Ascomycota) (Nash 1996, Purvis 2000). They are mushrooms with a specific nutritional strategy, involving the absorption of carbon from the autotrophic photobiont cells. Lichens are a polyphyletic group of organisms to be treated as an ecological, and not as a distinct taxonomic unit (HoNegGer 1998). The dual nature of lichens is expressed by numerous features. One of them is particularly high sensitivity to changes in habitat conditions caused by natural and anthropogenic factors (FAŁTYNowicz 1995, PuRvis 2000). The main reasons causing the extinction, the disappearance of stands and shrinking ranges of the native ingredients of lichen biota include:

- direct actions - the physical elimination of the species as a result of the destruction of their positions, e.g. cutting down trees,

- indirect actions - changing of environmental conditions, e.g. air pollution, soil and water contamination with toxic substances, acquiring land for building and communications infrastructure, quarrying, surface mining, mass tourism (CZYŻEWSKa 2003a, b).

Lichen thallus is characterised by large hygroscopic properties, allowing to collect water from the atmosphere. In contrast to plants, lichens are charac- terised by high resistance to factors such as extreme temperatures, lack of water and short growing period, yet highest sensitivity to air pollution (FAŁTYNOwICZ 1995). For more than 140 years lichens have been considered one of the best bioindicators of air pollution (NYLANDER 1866).

Areas with particularly heavy impact of civilization on the environment are cities. Lichens due to their characteristics, including sensitivity to atmospheric pollution by sulfur dioxide and nitrogen oxides occurring in urban areas, have become very popular bioindicators (Gries 1996, MatwiejuK \& KoROBKIEWICZ 2012a, b, ADAMSKA 2014).

One of the methods of bioindication that uses lichens as indicator organisms is lichenoindication. Among the lichenoindication methods four basic groups can be distinguished: floral methods (involving the study of diversity and abundance of lichens), anatomical-morphological methods (involving the examination of changes in the morphology and anatomy of lichen thallus), physiological methods (consisting of assessing changes in the activity of life processes) or methods of analytical chemistry (involving the analysis of the chemical composition of lichens: i.e. micro- and macro-elements accumulating in their biological structure; FAŁTYNOWICZ 1995, K£Os 2007). Floral methods, indicator species methods (Hawksworth \& Rose 1970, KiszKa 1990, Śliwa 2000, Bojko 2007, Matwiejuk 2007, BieLEC 2011, ADAMSKa 2014), analysis of participation of morphological forms (FAtTYNOWicz 1995, KePEL 
1999), as well as methods of analytical chemistry (Seaward 1973, Kiszka 1991, Pišut \& Lackovičova 1991, BylińsKa \& SeAward 1993, Matwiejuk 2007), anatomical and physiological (Brodo 1961, Pišut \& LACKOVIČOva 1991, PustelNiak 1991), and physiological methods (FERry \& Coppins 1979, FabISZEWSKi et al. 1983, Miszalski \& NiewiadomsKa 1993) have been used in Poland and in many countries.

The most frequently used method in Polish cities to assess the state of the environment by using lichens is the floristic method - lichen scale, consisting in determining the distribution in the studied site of selected, arboreal indicator species that distinguish zones of different degrees of pollution (eg. ZuRZYCKI 1950, CieśLIŃSKI 1974, KISZKA 1977, 1990, 1999, Wilkoń-Michalska et al. 1988, FatTynowicz et al. 1991, Kiszka \& KośCielniak 1996, Kepel 1999, Matwiejuk 2007, Matwiejuk \& Korobkiewicz 2012b, Matwiejuk 2014). Lichen scales link the occurrence of the species of lichens with air quality in the study area. The first scale of sensitivity of lichens was a scale developed for the British Isles (Hawksworth \& Rose 1970). Based on the occurrence of particular species of epiphytic lichens growing on trees of two different types of bark - eutrophized and uneuthrophized - HAwKsworth \& Rose (1970) developed a 10-point biological scale, in which for each grade they assigned the corresponding average concentrations of $\mathrm{SO}_{2}$ in the winter months. With this scale it has become possible to compare the distribution of zones in the different areas and the analysis of their changes over time. In Poland, the biological scale by HAWKSWORTH \& ROSE (1970) was modified and adapted to the conditions of the southern Poland by KIsZKA (1990, 1999) for the province of Kraków and Przemyśl. Using the term "lichenoindication zone" the author singled out seven zones.

Kiszka (1977), Kepel (1999), Matwiejuk (2007) developed lichenoindication scales including species inhabiting anthropogenic rocky ground (concrete poles), and placed them as indicator species in the lichenoindication zones.

The aim of the work is lichenoindication assessment by developing a lichen scale and preparing a lichenoindication map for Łomża.

\section{STUDY AREA}

Łomża is a town located in the north-eastern part of Poland, in the western part of the Podlaskie Voivodeship, just $150 \mathrm{~km}$ from Warsaw and $81 \mathrm{~km}$ from Białystok. The city is located at $53^{\circ} 11^{\prime} \mathrm{N}$ latitude and $22^{\circ} 04^{\prime} E$ longitude. According to the physical and geographical division of Poland the city area is within the two mesoregions: the Łomża Doab and the Valley of the Lower Narew included in the Północnomazowiecka Lowland. In terms of the geobotanical division the area of the city lies in the Ma-
zowiecko-Poleski Divide, in Mazowiecki Subdivide, in the Północnomazowiecko-Kurpiowska Region, in Kurpiowska Subregion, in the Łomża Doab District (Matuszkiewicz 2008). The city is located in the middle reaches of the river Narew, situated in the moraine hills, covering high, left bank embankment of meltwater valley of the Narew. The city is adjacent to the forest reserve "Rycerski Kierz" in the north and from the river Narew to the Łomża Landscape Park of the Narew Valley. Nearby, approx. $25 \mathrm{~km}$ northeast of the city, the Biebrza National Park is located and approx. $20 \mathrm{~km}$ northwest the Kurpiowska Forest (ZALUPKA 2008).

The city covers an area of $32.72 \mathrm{~km}^{2}$ (3.271 ha), including green areas of $29.91 \mathrm{ha}$. Among them there are three city parks - the Jakub Waga Park, People's Park and Pope John Paul II the Pilgrim Park, which cover an area of 17.78 ha (representing $0.91 \%$ of the city) and squares, green areas and places of national remembrance constituting 12.13 ha. Urban forests occupy 17 ha (which represents $0.52 \%$ of the total area of the city) and are only privately owned. The largest area of the city is occupied by arable land and permanent meadows, which are respectively $29 \%$ and $15 \%$ of the total area of Łomża. Residential areas occupy $13 \%$ of the total area of the city (JASTRZĘBSKI 2004).

Buildings in Łomża are evenly spaced on. The urban layout of the oldest district of the city - the Old Town presents the medieval assumptions, as it is characterised by a rectangular arrangement of streets and blocks of buildings (wikipedia.org/wiki).

The city is located in the transitional temperate climate zone. The average annual temperature is $7.1^{\circ} \mathrm{C}$ while the humidity fluctuates in the range of $80-82 \%$. The growing season lasts about 200 days. In the vicinity of Łomża west and south-west winds prevail. The average annual wind speed varies between $3.0-3.5 \mathrm{~m} / \mathrm{s}$ (ZALUPKA 2008 ).

In 2014, in the city the population was 62779 , which places the city in this respect on the 3rd place in the Podlaskie Voivodeship (GUS 2014).

The location of Łomża in the region of an agricultural and forest character indicates the basic directions of economic development, which are the sectors unobtrusive ecologically, i.e. food, brewing, electronics, building materials, wood, furniture, production and processing of agricultural products, as well as tourism and agrotourism (JASTRZĘBSKI 2004).

The main sources of air pollution emissions in Łomża are point sources: urban heating plant MPEC, PEPEES JSC Food Industry Company, Łomża Brewery, Food Plant "Bona" and the District Dairy Cooperative in Piątnica. Traffic routes run through the city, such as the national road 61,63 and provincial roads $645,677,679$. The volume of emissions in Łomża in 2014 is presented in Table 1. 
Table 1. Emissions of pollutants in Łomża in 2014

\begin{tabular}{cccc}
\hline \multicolumn{4}{c}{ Emissions in $2014\left(\mu \mathrm{g} / \mathrm{m}^{3}\right)$} \\
\hline $\mathrm{SO}_{2}$ & $\mathrm{NO}_{2}$ & dust PM 10 & dust PM 2.5 \\
6.5 & 15.9 & 29.5 & $28.0^{*}$ \\
\hline
\end{tabular}

*Exceeding the permissible level.

Source: WIOŚ Białystok.

\section{MATERIALS AND METHODS}

Field studies were conducted in the years 20142015 , for 34 research positions (Table 2). The study included the area of Łomża in its administrative boundaries. A detailed floristic analysis of epiphytic species growing on the bark of deciduous (Acer negundo, A. platanoides, A. pseudoplatanus, A. saccharinum, Aesculus hippocastanum, Betula pendula, Carpinus betulus, Fagus sylvatica, Fraxinus excelsior, F. pennsylvanica, Platanus acerifolia, Populus balsamifera, P. tremula, Quercus robur, Rhus typhina, Robinia pseudoacacia, Salix alba, Sorbus aucuparia, S. domestica, S. intermedia, Symphoricarpus albus, Tilia cordata, T. platyphyllos) and coniferous trees (Larix decidua, Picea abies, Pinus nigra, P. sylvestris) and epilithic species inhabiting concrete surfaces (columns, walls) and data on their distribution form the basis for the development of lichen scale and designation of lichenoindication zones for Łomża. For each zone a list of indicator species found in Łomża has been compiled (Table 3). The lichen scale developed for Łomża in the years 2014-2015 is based on the modified scale of Hawksworth and Rose (Hawksworth \& Rose 1970, KiszKa 1977, 1990, 1999, Kepel 1999, Matwiejuk 2007, Adamska 2014). The lichenoindication scale of the studied area given according to KiszKa (1977), Kepel (1999), MatwiejuK (2007) includes rock species preferring concrete substrata - concrete pillars. The nomenclature of lichens was adopted according to DieDERICH et al. (2015), except for the following taxa Melanohalea exasperatula (BlANCO et al. 2004) and Melanelixia fuliginosa (ARuP \& SANDler Berlin 2011), Circinaria calcarea (Nordin et al. 2010), Calogaya decipiens, C. pusilla, Flavoplaca citrina, F. oasis, Polycauliona polycarpa, Rusavskia elegans (Arup et al. 2013).

\section{RESULTS}

In the area of Łomża were found 32 species of lichens indicator, including 22 epiphytes and 13 epilythes at 34 localities (Table 2).

\section{LIST OF INDICATOR SPECIES OF EPIPHYTIC AND EPILYTHIC IN ŁOMŻA}

Buellia punctata (Hoffm.) A. Massal. - bark of Acer platanoides, Tilia cordata; locality: 6 .

Calogaya decipiens (Arnold) Arup, Frödén \& Søchting - concrete; localities: 1, 11, 15, 21, 25, 28.
Calogaya pusilla (A. Massal.) Arup, Frödén \& Søchting - concrete; localities: 1, 11, 15, 23, 25, 28, 31.

Candelariella aurella (Hoffm.) Zahlbr. - concrete; locality: 19.

Candelariella xanthostigma (Ach.) Lettau - bark of Acer pseudoplatanus, Betula pendula, Fraxinus excelsior, Pinus sylvestris, Salix alba, Sorbus domestica, Tilia cordata, T. platyphyllos; localities: 12, 14, 18, 27, 29, 32, 34.

Evernia prunastri (L.) Ach. - bark of Acer platanoides, A. saccharinum, Fraxinus excelsior, Populus tremula, Tilia cordata, T. platyphyllos; localities: 3, 8, 9, 17, 24.

Flavoplaca citrina (Hoffm.) Arup, Frödén \& Søchting - concrete; locality: 19.

Flavoplaca oasis (A. Massal.) Arup, Frödén \& Søchting - concrete; locality: 19.

Hypocenomyce scalaris (Ach.) M. Choisy - bark of Acer platanoides, Aesculus hippocastanum, Tilia cordata; locality: 1.

Hypogymnia physodes (L.) Nyl. - bark of Acer saccharinum, Betula pendula, Picea abies, Pinus sylvestris, Sorbus aucuparia, S. intermedia, Tilia cordata, T. platyphyllos; localities: 7, 12, 14, 16, 22, 27, 29, 34.

Hypogymnia tubulosa (Schaer.) Hav. - bark of Tilia cordata; locality: 17.

Lecanora albescens (Hoffm.) Flörke - concrete; localities: 6, 19.

Lecanora dispersa (Pers.) Sommerf. - concrete; localities: 6, 19.

Lecanora muralis (Schreb.) Rabenh. - concrete; localities: 1, 4, 11, 15, 21, 23, 25, 28, 31.

Lecanora pulicaris (Pers.) Ach. - bark of Acer platanoides, A. saccharinum, Fraxinus excelsior, Sorbus intermedia, Tilia cordata; localities: 18, 22, 34.

Lepraria sp. - bark of Tilia cordata; locality: 6 .

Melanohalea exasperatula (Nyl.) O. Blanco, A. Crespo, Divakar, Essl., D. Hawksw. \& Lumbsch - bark of Acer platanoides, Sorbus aucuparia, S. intermedia, Tilia cordata; localities: 16, 22, 32, 34.

Parmelia sulcata Taylor - bark of Acer platanoides, Betula pendula, Picea abies, Sorbus intermedia, Tilia cordata, T. platyphyllos; localities: 7, 12, 14, 22, 27, 32, 34.

Phaeophyscia orbicularis (Neck.) Moberg - bark of Acer platanoides, A. pseudoplatanus, Aesculus hippocastanum, Betula pendula, Carpinus betulus, Fraxinus excelsior, Populus tacamahaca, Quercus robur, Salix alba, Sorbus domestica, Symphoricarpus albus, Tilia cordata, concrete; localities: 1, 2, 5, 7, 10-12, 14$16,18,21-23,27,29,32,34$.

Physcia adscendens H. Olivier, nom. cons. - bark of Acer platanoides, Betula pendula, Fagus sylvatica, Fraxinus excelsior, Symphoricarpus albus, Tilia cordata, T. platyphyllos, cocnrete; localities: $1,5,11,12$, 14-16, 18, 21, 22, 27, 32, 34.

Physcia aipolia (Humb.) Fürnr. - bark of Tilia cordata; locality: 14. 
Table 2. List of positions of occurrence of indicator species of epiphytic and epilythic in Łomża

\begin{tabular}{|c|c|c|}
\hline No. & Location & Substrate \\
\hline 1 & Mikołaj Kopernik Street & $\begin{array}{l}\text { Acer platanoides, Aesculus hippocastanum, Fraxinus excelsior, Tilia cordata, } \\
\text { beton }\end{array}$ \\
\hline 2 & Mikołaj Kopernik Street & $\begin{array}{l}\text { Acer negundo, A. platanoides, A. saccharinum, Fraxinus pennsylvanica, Platanus } \\
\text { acerifolia, Populus tremula, Rhus typhina }\end{array}$ \\
\hline 3 & Rybaki Street & Populus tremula \\
\hline 4 & Boczna Street & concrete \\
\hline 5 & Avenue of Legions & $\begin{array}{l}\text { Acer platanoides, A. pseudoplatanus, Carpinus betulus, Fagus sylvatica, Fraxinus } \\
\text { excelsior, Pinus nigra, Quercus robur, Q. rubra, Salix alba }\end{array}$ \\
\hline 6 & Wojska Polskiego Street & Acer platanoides, Tilia cordata, concrete \\
\hline 7 & Przykoszarowa Street & Betula pendula, concrete \\
\hline 8 & Grobla Jednaczewska Street & Acer platanoides, Fraxinus excelsior, Tilia cordata, T. platyphyllos \\
\hline 9 & Pope John Paul II the Pilgrim Park & Acer platanoides \\
\hline 10 & Julian Ursyn Niemcewicz Street & Betula pendula, Larix decidua, Robinia pseudoacacia, Rhus typhina, Tilia cordata \\
\hline 11 & Władysław Sikorski Street & Acer platanoides, Fraxinus excelsior, Sorbus domestica, concrete \\
\hline 12 & Niepodległości Square & $\begin{array}{l}\text { Acer platanoides, A.pseudoplatanus, Populus tremula, Salix alba, Sorbus domes- } \\
\text { tica, Tilia platyphyllos, concrete }\end{array}$ \\
\hline 13 & Fabryczna Street & concrete \\
\hline 14 & Senatorska 13 Street & Acer platanoides, Betula pendula, Tilia cordata, concrete \\
\hline 15 & Piękna Street & $\begin{array}{l}\text { Acer platanoides, A. pseudoplatanus, Betula pendula, Sorbus intermedia, Sym- } \\
\text { phoricarpus albus, Tilia cordata, concrete }\end{array}$ \\
\hline 16 & Nowogrodzka 60 Street & Sorbus intermedia, concrete \\
\hline 17 & Marszałek Józef Piłsudski Street & Acer platanoides, Tilia cordata \\
\hline 18 & Wojska Polskiego Street & Acer negundo, A. platanoides, Fraxinus excelsior, Tilia cordata, concrete \\
\hline 19 & Adam Mickiewicz Street & concrete \\
\hline 20 & Kaktusowa Street & concrete \\
\hline 21 & Farna Street & Tilia cordata, T. platyphyllos, concrete \\
\hline 22 & Księżna Anna Street & $\begin{array}{l}\text { Acer pseudoplatanus, A. saccharinum, Betula pendula, Picea abies, Sorbus aucu- } \\
\text { paria, S. intermedia, concrete }\end{array}$ \\
\hline 23 & Poznańska 148 Street & Populus balsamifera, concrete \\
\hline 24 & $\begin{array}{l}\text { Józef Bem Street, from Władysław Broniewski Street } \\
\text { to Władysław Reymont Street }\end{array}$ & Acer saccharinum \\
\hline 25 & Kręta Street & concrete \\
\hline 26 & Janusz Korczak Street & concrete \\
\hline 27 & $\begin{array}{l}\text { Piaski Street (from Świerkowa Street to the Podleś- } \\
\text { na Street) }\end{array}$ & Tilia cordata, concrete \\
\hline 28 & Piwna Street & concrete \\
\hline 29 & Poligonowa Street & Pinus sylvestris, concrete \\
\hline 30 & $\begin{array}{l}\text { Marszałek Józef Piłsudski Street (from Poznańska } \\
\text { Street to the Spokojna Street) }\end{array}$ & concrete \\
\hline 31 & Zjazd Street & Tilia cordata, concrete \\
\hline 32 & Highway to Mężenin & Tilia cordata, concrete \\
\hline 33 & Avenue of Legions & Fraxinus excelsior \\
\hline 34 & Szosa Zambrowska Street & Acer platanoides, Fraxinus excelsior, Tilia cordata, concrete \\
\hline
\end{tabular}


Physcia dubia (Hoffm.) Lettau var. dubia - bark of Acer platanoides, Betula pendula, Fagus sylvatica, Fraxinus excelsior, F. pennsylvanica, Larix decidua, Pinus nigra, Populus tacamahaca, P. tremula, Quercus rubra, Salix alba, Sorbus domestica, S. intermedia, Tilia cordata; localities: 1, 2, 5, 10, 11, 15, 21, 23, 34.

Physcia tenella (Scop.) DC. - concrete; localities: 7, $18,22,27,32$.

Physconia grisea (Lam.) Poelt - bark of Acer negundo, Fraxinus excelsior, Populus tremula, Salix alba, Sorbus intermedia; localities: 12, 16, 18.

Pseudevernia furfuracea (L.) Zopf - bark of Fraxinus excelsior; locality: 8.

Polycauliona polycarpa (Hoffm.) Frödén, Arup \& Søchting - bark of Acer platanoides, Betula pendula, Robinia pseudoacacia, Sorbus intermedia; localities: 10, 11, 15.

Ramalina farinacea (L.) Ach. - bark of Fraxinus excelsior; localities: 8.

Ramalina fastigiata (Pers.) Ach. - bark of Fraxinus excelsior; localities: 8, 33.

Ramalina fraxinea (L.) Ach. - bark of Acer platanoides, Fraxinus excelsior, Sorbus intermedia, Tilia cordata; localities: 8, 17, 33.

Rusavskia elegans (Link) S.Y. Kondr. \& Kärnefelt concrete; localities: 9, 13, 20, 24, 26, 30.

Scoliciosporum chlorococcum (Stenh.) Vězda - bark of Betula pendula; locality: 6 .

Xanthoria parietina (L.) Th. Fr. - bark of Acer platanoides, A. pseudoplatanus, A. saccharinum, Betula pendula, Fraxinus excelsior, F. pennsylvanica, Larix decidua, Pinus nigra, Platanus acerifolia, Populus balsamifera, Quercus rubra, Rhus typhina, Robinia pseudoacacia, Salix alba, Sorbus domestica, S. intermedia, Symphoricarpus albus, Tilia cordata, T. platyphyllos; localities: 1, 2, 5, 7, 10-12, 14-16, 18-19, 21-23, 27, 29, 31-32, 34.

On the basis of the lichenoindical research in Łomża appointed occurrence of four lichenoindication zones (Table 3, Fig. 1).

ZONE II - relative lichen desert.

Only two localities situated in the city center, the Jakub Waga Park, and Adam Mickiewicz Street show signs of zone II. The zone has been determined on the basis of the presence of epiphytic crustose lichens resistant to phytotoxic compounds, such as Buellia punctata, Lepraria sp., Scoliciosporum chlorococcum and epilithic lichens inhabiting rocky ground, such as Candelariella aurella, Flavoplaca citrina, F. oasis, Lecanora albescens, L. dispersa.

ZONE III - internal zone of limited vegetation.

The zone covers the city center of Łomża and the areas situated in the north-eastern part of the city along national route 61 , where there is the greatest amount of traffic. Within this zone there are areas where factories are located, such as PEPEES JSC Food Industry Company, Łomża Brewery, Food Plant "Bona" and the thermal power station as well as the urban areas along the national road 63 . There is a high-density housing here, making it difficult to ventilate the area and causing air stagnation. In this zone mainly the presence of lichens with fruticose thalli has been recorded, such as: Phaeophyscia orbicularis, Physcia adscendens, P. dubia, Polycauliona polycarpa, Xanthoria parietina and with squamulose thalli - Hypocenomyce scalaris. Lichens form a thallus of small size and cover the bark of trees to a small degree. In the center of the town there are few trees compared with its outskirts, and therefore concrete surfaces are more often colonized by lichens. In this zone on the concrete structures there are increasing numbers of placodial thallus: Calogaya decipiens, C. pusilla and Lecanora muralis.

ZONE IV - middle zone of limited vegetation. Zone IV is characterized by a less compact housing than zone III. The species found here are: Hypogymnia physodes (recorded on 8 localities), Melanohalea exasperatula (4) and Physconia grisea (3). This zone covers a substantial peripheral part of the city.

ZONE V - outer zone of limited vegetation. Zone $\mathrm{V}$ is located in green areas, including the areas of the river and park. It covers nine posts: Jewish cemetery at Rybaki Street, located on the border with the Łomża Landscape Park of the Narew Valley (locality 3), the area bordering the "Rycerski Kierz" reserve (locality 8), Pope John Paul II the Pilgrim Park (locality 9), Fabryczna Street (locality 13), the area around the Provincial Hospital at Marszałek

Table 3. Scale lichens developed for Łomża in 2014-2015 on the basis of modified scale Hawksworth and Rose (HAwKSwORTH \& Rose 1970, KiszKa 1977, 1999, Matwiejuk 2007, Adamska 2014)

\begin{tabular}{|c|c|c|c|}
\hline Zone & Indicator species growing on the bark of trees & Indicator species growing on the concrete & Notes on distribution \\
\hline II & $\begin{array}{l}\text { Buellia punctata, Lepraria sp., Scoliciosporum } \\
\text { chlorococcum }\end{array}$ & $\begin{array}{l}\text { Lecanora dispersa, } L . \text { albescens, Candelariella aurella, } \\
\text { Flavoplaca citrina, F. oasis }\end{array}$ & 2 localities: 6,19 \\
\hline III & $\begin{array}{l}\text { Hypocenomyce scalaris, Phaeophyscia orbicularis, } \\
\text { Physcia adscendens, P. dubia, Polycauliona polycarpa, } \\
\text { Xanthoria parietina }\end{array}$ & $\begin{array}{l}\text { Calogaya decipiens, C. pusilla, } \\
\text { Lecanora muralis }\end{array}$ & $\begin{array}{l}12 \text { localities: } 1,2,4,5,10 \text {, } \\
11,15,21,23,25,28,31\end{array}$ \\
\hline IV & $\begin{array}{l}\text { Candelariella xanthostigma Hypogymnia physodes, } \\
\text { Lecanora pulicaris, Melanohalea exasperatula, Par- } \\
\text { melia sulcata, Physcia aipolia, Physconia grisea }\end{array}$ & $\begin{array}{l}\text { Phaeophyscia orbicularis, } \\
\text { Physcia adscendens, P. tenella, Xanthoria parietina }\end{array}$ & $\begin{array}{l}10 \text { localities: } 7,12,14,16 \text {, } \\
18,22,27,29,32,34\end{array}$ \\
\hline V & $\begin{array}{l}\text { Hypogymnia tubulosa, Evernia prunastri, Pseudever- } \\
\text { nia furfuracea, Ramalina farinacea, } \\
\text { R. fastigiata, R. fraxinea }\end{array}$ & Rusavskia elegans & $\begin{array}{l}10 \text { localities: } 3,8,9,13 \\
17,20,24,26,30,33\end{array}$ \\
\hline
\end{tabular}




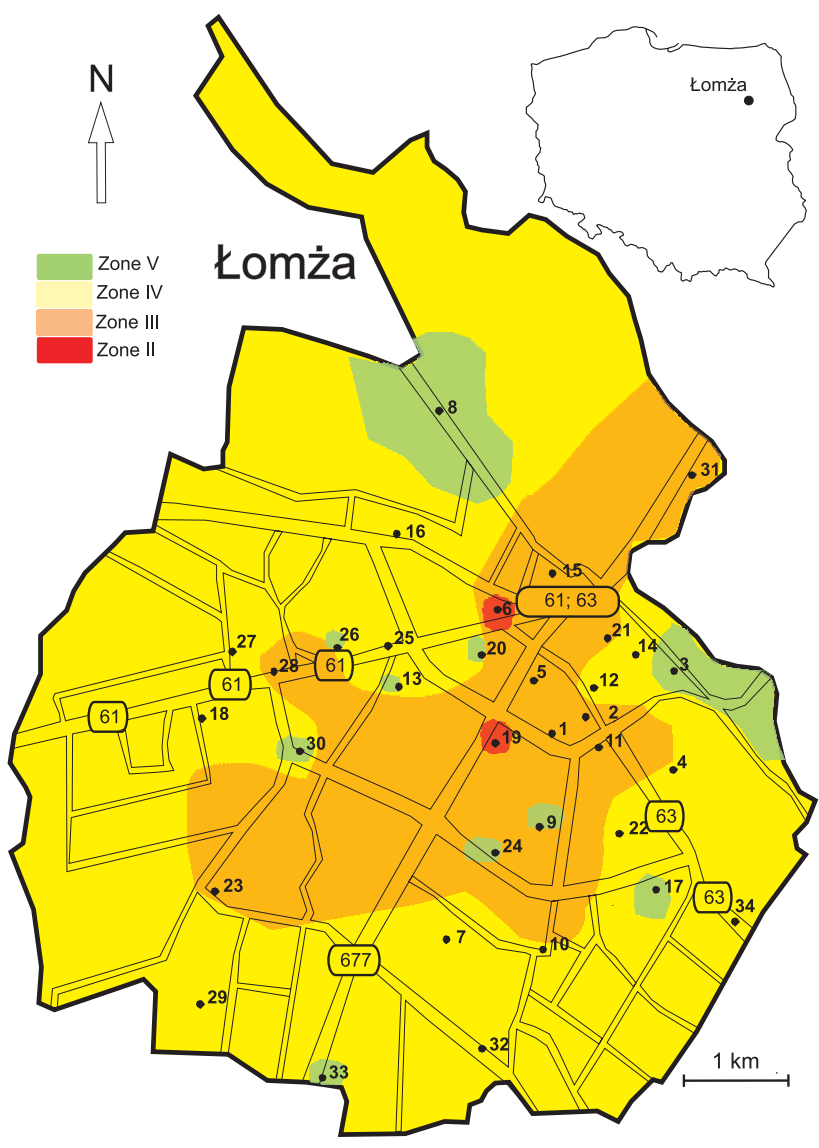

Fig. 1. Lichenoindications zones in Łomża city

Józef Piłsudski Street (locality 17), Kaktusowa Street (locality 20), Józef Bem Street (locality 24), Janusz Korczak Street in the district Łomżyca (locality 26), Avenue of Legions around the road leading out of town towards Konarzyce (locality 33). The location of the positions characteristic of zone V in Łomża is mainly of point character, with the exception of areas bordering the Narew river, near the border with the Łomża Landscape Park of the Narew Valley.

The species recorded in this zone are epiphytic macrolichens (foliose and fruticose) with well-developed thalli, such as: Ramalina fraxinea (recorded in 3 localities), R. fastigiata (2), Hypogymnia tubulosa, Pseudevernia furfuracea, Ramalina farinacea (1).

Epilithic lichen species which are assigned to individual lichenoindication zones, were divided according to WIRTH (1995) into three categories in terms of habitat preferences: 1 . calciphilous, obligatory - tied exclusively to limestone surfaces, both natural and artificial, 2. calciphilous, optional - found on other basic substrata, and 3. uncalciphilous lichens - with a wide ecological range, present both at basic and acidic substrata or transferred to other substrates.

Among the lichens that inhabit concrete structures calciphilous (optional) lichens including Candelariella aurella, Flavoplaca citrina, F. oasis, Lecanora albescens, L. dispersa and Rusavskia elegans dominate. Calciphilous (obligatory) lichen is Calogaya decipiens and uncalciphilic are Lecanora muralis, Physcia adscendens, P. tenella, Flavoplaca oasis and Xanthoria parietina.

\section{DISCUSSION AND CONCLUSION}

Łomża near Białystok (Matwiejuk 2007), Narew city (Matwiejuk \& KorobKiewicz 2012 b), and Sokółka (Matwiejuk 2014) is the fourth city in the Podlasie region where lichen vegetation zones have been designated. In the area of Sokółka, there were no lichen deserts present: zone I (absolute lichen desert) and zone II (relative lichen desert). Narew and Białystok stand out among other Polish cities, where the lichenoindication research was conducted, due to point distribution of stands with the characteristics of the lichen desert zone. In the area of Łomża, there was no lichen zone I, while zone II was found only in two localities.

Absolute lichen desert zones in other cities occupy large areas. Lichen deserts were separated in Kraków (ZuRZYCKi 1950, KIsZKa 1977, KIsZKA \& KościelniaK 1996), Torun (WilkoŃ-MichalsKa et al. 1988), Radom (CIEŚLIŃSKI 1974), Warsaw (ZIMNY \& KUCIŃSKA 1974), Łódź (KuzIel \& Halicz 1979), Szczecin (MarsKa 1979), urban agglomeration Tricity (FAtTYNowicz et al. 1991), Karpacz (BYlińsKa \& Seaward 1993), Poznań (Kepel 1999) and Starogard Gdański (FAŁTYNowicz 2001). Absolute lichen desert zones in many cities coincide with areas of high air pollution. Only seven cities did not register this zone: Kielce (ToBorowicz 1976), Drezdenko (LIPNicki 1984), Przemyśl (KiszKa 1999), Olsztyn (KubiaK 2004), Wrocław (BojKo 2006), Kielce (ŁuBeK 2010), Sokółka (Matwiejuk 2014), Toruń (AdAmsKa 2014).

The phenomenon of impoverishment of the lichen biota was observed in the cities where the lichenoindication research had been conducted at the end of the 1990s (KiszKa \& KościelniaK 1996, Kepel 1999, ŚLIwA 2000). Since the 1990s, the trend has been the reduction of emissions in Poland and the return of lichens to the cities (KUвIAK 2004, BоJKO 2007, ŁUвEK 2010, Adamska 2014, Matwiejuk 2014).

In many cities, it was found that the spatial arrangement of lichen vegetation zones is associated with beneficial effects of green complexes and the movement of dust and gas in accordance with the morphology of the terrain, especially with the course of the river valleys and direction of winds (MATwiEjuK 2007, Matwiejuk \& KorobKiewicz 2012).

The results of the deployment of individual lichenoindication zones in Łomża and Białystok in relation to the background of air pollution confirms that in Białystok, where lower concentrations of $\mathrm{SO}_{2}$ were found, zonal distribution of zone $\mathrm{V}$ was noted (Table 4). In the area of Łomża a clear point prevalence of this zone was marked, restricted to single sites located in the green areas and in the areas 
Table 4. Summary of emissions for Łomża and Białystok, where research was conducted

\begin{tabular}{lccccc}
\hline \multirow{3}{*}{ City } & \multicolumn{5}{c}{ Emissions in $2014\left(\mu \mathrm{g} / \mathrm{m}^{3}\right)$} \\
\cline { 2 - 6 } & $\mathrm{SO}_{2}$ & $\mathrm{NO}_{2}$ & dust PM & dust PM & \multirow{2}{*}{$\mathrm{CO}$} \\
\hline Łomża & 6.5 & 15.9 & 29.5 & 28.5 & \\
Białystok & 4.3 & 13.7 & 29.9 & b/d & 330 \\
\hline
\end{tabular}

b.d. - no data.

Source: WIOŚ Białystok.

bordering the river Narew, near the border with the Łomża Landscape Park of the Narew Valley and reserve "Rycerski Kierz". In the area of Białystok the outer zone of limited vegetation covers the forest areas (Matwiejuk 2007).
Due to the relatively high level of concentration of $\mathrm{SO}_{2}$ in the air in Łomża the most vulnerable filamentous fronds of lichens from genus Usnea and Bryoria were not found in zone V. However, these lichens were recorded in zone $\mathrm{V}$ in the capital of Podlasie (MATwIEJUK 2007). In the city of Łomża sensitive lichens of fruticose thalli, such as: Evernia prunastri, Ramalina farinacea, $R$. fastigiata, $R$. fraxinea are found in few localities.

The analysis of the data published shows that the species composition of lichens in the zones may be different in different parts of Poland (KIsZKA 1977, Kepel 1999, Matwiejuk 2007, Bielec 2011, AdamsKa 2014) (Tables 5, 6). Therefore, there is need to modify the lichen scale to the prevailing conditions and the composition of the local biota of lichens.

Table 5. List of indicator species of epiphytic selected Polish cities

\begin{tabular}{|c|c|c|c|c|c|c|}
\hline Zone & Łomża & $\begin{array}{c}\text { Kraków } \\
\text { (KiszKA 1977) }\end{array}$ & $\begin{array}{c}\text { Poznań } \\
\text { (KEPEL 1999) }\end{array}$ & $\begin{array}{c}\text { Białystok } \\
\text { (MATWIEJUK 2007) }\end{array}$ & $\begin{array}{l}\text { Bielsko-Biała } \\
\text { (BIELEC 2011) }\end{array}$ & $\begin{array}{c}\text { Toruń } \\
\text { (ADAMSKA 2014) }\end{array}$ \\
\hline II & $\begin{array}{l}\text { Buellia punctata, } \\
\text { Lepraria sp., } \\
\text { Scoliciosporum } \\
\text { chlorococcum }\end{array}$ & $\begin{array}{l}\text { Phaeophyscia } \\
\text { orbicularis, Physcia } \\
\text { adscendens, } \\
\text { P. dubia, } \\
\text { Physconia grisea }\end{array}$ & $\begin{array}{l}\text { Lecanora conizaeoi- } \\
\text { des, Lepraria sp. }\end{array}$ & $\begin{array}{l}\text { Buellia punctata, } \\
\text { Lecanora conizaeoides, } \\
\text { Lepraria sp., Scoliciosporum } \\
\text { chlorococcum }\end{array}$ & $\begin{array}{l}\text { Buellia punctata, } \\
\text { Cladonia bacillaris, } \\
\text { Lecanora conizae- } \\
\text { oides, } \\
\text { L. expallens, } \\
\text { L. sarcopis, Lepraria } \\
\text { incana, Phaeophy- } \\
\text { scia adscendens }\end{array}$ & $\begin{array}{l}\text { Buellia punctata, } \\
\text { Lecanora conizaeoi- } \\
\text { des, Phaeophyscia } \\
\text { orbicularis, Physcia } \\
\text { tenella, Polycauliona } \\
\text { candelaria, } \\
\text { P. polycarpa, Xan- } \\
\text { thoria parietina }\end{array}$ \\
\hline III & $\begin{array}{l}\text { Hypocenomyce } \\
\text { scalaris, Phaeo- } \\
\text { physcia orbicu- } \\
\text { laris, Physcia } \\
\text { adscendens, } \\
\text { P. dubia, } \\
\text { Polycauliona poly- } \\
\text { carpa, Xanthoria } \\
\text { parietina }\end{array}$ & $\begin{array}{l}\text { Arthonia ruana, } \\
\text { Evernia prunastri, } \\
\text { Flavopermalia ca- } \\
\text { perata, Hypogymnia } \\
\text { physodes, Parmelia } \\
\text { sulcata, Parmeliop- } \\
\text { sis ambigua, Tucker- } \\
\text { manopsis sepincola, } \\
\text { Xanthoria parietina }\end{array}$ & $\begin{array}{l}\text { Buellia punctata, } \\
\text { Hypocenomyce } \\
\text { scalaris, } \\
\text { Physcia } \\
\text { adscendens, } \\
\text { P. tenella, Xanthoria } \\
\text { parietina }\end{array}$ & $\begin{array}{l}\text { Candelariella xanthostima, } \\
\text { Hypocenomyce scalaris, } \\
\text { Hypogymnia physodes, } \\
\text { Parmelia sulcata, Phaeophy- } \\
\text { scia orbicularis, } \\
\text { Physcia dubia, } \\
\text { P. adscendens, Polycauliona } \\
\text { polycarpa, } \\
\text { Xanthoria parietina }\end{array}$ & $\begin{array}{l}\text { Chaenotheca ferru- } \\
\text { ginea, Hypoceno- } \\
\text { myce scalaris, Hy- } \\
\text { pogymnia physodes, } \\
\text { Lecanora chlarotera, } \\
\text { Parmelia sulcata, } \\
\text { Phaeophyscia } \\
\text { orbicularis, Physcia } \\
\text { adscendens }\end{array}$ & $\begin{array}{l}\text { Candelaria pacifica, } \\
\text { Hypocenomyce } \\
\text { scalaris, Hypogymnia } \\
\text { physodes, Lecanora } \\
\text { chlarotera, Melano- } \\
\text { halea exasperatula, } \\
\text { Parmelia sulcata, } \\
\text { Physcia stellaris, } \\
\text { Scoliciosporum } \\
\text { chlorococcum }\end{array}$ \\
\hline IV & $\begin{array}{l}\text { Candelariella xan- } \\
\text { thostigma Hypo- } \\
\text { gymnia physodes, } \\
\text { Lecanora pulicaris, } \\
\text { Melanohalea exas- } \\
\text { peratula, Parmelia } \\
\text { sulcata, } \\
\text { Physcia aipolia, } \\
\text { Physconia grisea }\end{array}$ & $\begin{array}{l}\text { Hypogymnia physo- } \\
\text { des, Flavoparmelia } \\
\text { caperata, Imshaugia } \\
\text { aleurites, Pertusaria } \\
\text { amara, } \\
\text { Ramalina farinacea, } \\
\text { R. pollinaria }\end{array}$ & $\begin{array}{l}\text { Cladonia sp., Hypo- } \\
\text { gymnia physodes, } \\
\text { Parmelia sulcata, } \\
\text { Physcia dubia, } \\
\text { Physconia grisea, } \\
\text { Polycauliona poly- } \\
\text { carpa, Xanthoria } \\
\text { candelaria }\end{array}$ & $\begin{array}{l}\text { Anaptychia ciliaris, Bryoria } \\
\text { crispa, Candelaria concolor, } \\
\text { Candelariella xanthostigma, } \\
\text { Evernia prunastri, Hypo- } \\
\text { gymnia tubulosa, Lecanora } \\
\text { carpinea, L. pulicaris, Mela- } \\
\text { nelixia fuliginosa, Melano- } \\
\text { halea exasperatula, Physconia } \\
\text { exteoxantha, Platismatia } \\
\text { glauca, Pleurosticta acetabu- } \\
\text { lum, Pseudevernia furfuracea, } \\
\text { Ramalina farinacea, R. fra- } \\
\text { xinea, R. pollinaria, } \\
\text { Tuckermanopsis chlorophylla }\end{array}$ & $\begin{array}{l}\text { Candelaria concolor, } \\
\text { Evernia prunastri, } \\
\text { Lecanora carpinea, } \\
\text { Platismatia glauca, } \\
\text { Ramalina farinacea }\end{array}$ & $\begin{array}{l}\text { Coenogonium } \\
\text { pineti, Hypogymnia } \\
\text { tubulosa, Lecanora } \\
\text { carpinea, Melanelixia } \\
\text { glabratula, Phlyctis } \\
\text { argena, Pseudever- } \\
\text { nia furfuracea, } \\
\text { Pleurosticta aceta- } \\
\text { bulum, Parmeliopsis } \\
\text { ambigua, Ramalina } \\
\text { farinacea, R. polli- } \\
\text { naria }\end{array}$ \\
\hline V & $\begin{array}{l}\text { Evernia prunastri, } \\
\text { Hypogymnia tubu- } \\
\text { losa, Pseudevernia } \\
\text { furfuracea, Rama- } \\
\text { lina farinacea, } \\
\text { R. fastigiata, } \\
\text { R. fraxinea }\end{array}$ & $\begin{array}{l}\text { Cetrelia cetrarioides, } \\
\text { Evernia mesomor- } \\
\text { pha, Hypogymnia } \\
\text { tubulosa, Pseudever- } \\
\text { nia furfuracea, } \\
\text { Usnea hirta }\end{array}$ & $\begin{array}{l}\text { Candelariella xan- } \\
\text { thostigma, Evernia } \\
\text { prunastri, Hypo- } \\
\text { gymnia tubulosa, } \\
\text { Melanelia sp., Par- } \\
\text { meliopsis ambigua, } \\
\text { Platismatia glauca, } \\
\text { Pseudevernia furfu- } \\
\text { racea, Tuckermanop- } \\
\text { sis chlorophylla, } \\
\text { Vulpicida pinastri }\end{array}$ & $\begin{array}{l}\text { Arthonia radiata, Bryoria } \\
\text { crispa, B. vrangiana, Chae- } \\
\text { notheca ferruginea, Graphis } \\
\text { scripta, Imshaugia aleurites, } \\
\text { Parmalia saxatilis, Parmelina } \\
\text { tiliacea, Parmeliopsis ambigua, } \\
\text { Pertusaria albescens, P. amara, } \\
\text { Tuckermanopsis chlorophylla, } \\
\text { T. sepincola, Usnea hirta, } \\
\text { U. subfloridana, Vulpicida } \\
\text { pinastri }\end{array}$ & $\begin{array}{l}\text { There has been } \\
\text { this zone }\end{array}$ & $\begin{array}{l}\text { Ramalina fraxinea, } \\
\text { Usnea dasypoga, } \\
\text { U. hirta, Vulpicida } \\
\text { pinastri }\end{array}$ \\
\hline
\end{tabular}


Table 6. List of indicator species of epilythic selected Polish cities

\begin{tabular}{|c|c|c|c|c|}
\hline Zone & Łomża & $\begin{array}{c}\text { Kraków } \\
\text { (KISZKA 1977) }\end{array}$ & $\begin{array}{c}\text { Poznań } \\
\text { (KePEL 1999) }\end{array}$ & $\begin{array}{c}\text { Białystok } \\
\text { (MATWIEJUK 2007) }\end{array}$ \\
\hline II & $\begin{array}{l}\text { Candelariella aurella, Flavo- } \\
\text { placa citrina, F. oasis, Lecanora } \\
\text { albescens, L. dispersa }\end{array}$ & $\begin{array}{l}\text { Caloplaca lactea, Cande- } \\
\text { lariella aurella, Flavoplaca } \\
\text { citrina, Lecanora dispersa, } \\
\text { L. muralis, Physcia caesia }\end{array}$ & $\begin{array}{l}\text { Caloplaca holocarpa s.l., Can- } \\
\text { delariella aurella, C. vitellina, } \\
\text { Flavoplaca citrina, F. oasis, Lecanora } \\
\text { albescens, L. dispersa, Lecidella } \\
\text { stigmatea }\end{array}$ & $\begin{array}{l}\text { Candelariella aurella, Flavoplaca } \\
\text { citrina, F. oasis, Lecanora albescens, } \\
\text { L. dispersa, Phaeophyscia orbicularis }\end{array}$ \\
\hline III & $\begin{array}{l}\text { Calogaya decipiens, C. pusilla, } \\
\text { Lecanora muralis }\end{array}$ & $\begin{array}{l}\text { Calogaya decipiens, } \\
\text { C. pusilla, Lecanora muralis, } \\
\text { Phaeophyscia orbicularis }\end{array}$ & $\begin{array}{l}\text { Calogaya decipiens, C. pusilla, Cir- } \\
\text { cinaria calcarea, Lecanora muralis, } \\
\text { Phaeophyscia orbicularis }\end{array}$ & $\begin{array}{l}\text { Calogaya decipiens, C. pusilla, Leca- } \\
\text { nora muralis, Lecidella stigmatea }\end{array}$ \\
\hline IV & $\begin{array}{l}\text { Phaeophyscia orbicularis, } \\
\text { Physcia adscendens, } P \text {. tenella, } \\
\text { Xanthoria parietina }\end{array}$ & no substrates for lichens & $\begin{array}{l}\text { Phaeophyscia nigricans, Physcia } \\
\text { adscendens, } P \text {. caesia, } P \text {. dubia, P. te- } \\
\text { nella, Rufoplaca arenaria, Xanthoria } \\
\text { parietina }\end{array}$ & $\begin{array}{l}\text { Phaeophyscia nigricans, Physcia } \\
\text { adscendens, P. caesia, P. dubia, } \\
\text { P. tenella, Rufoplaca arenaria, Sarco- } \\
\text { gyne regularis, Xanthoria parietina }\end{array}$ \\
\hline $\mathrm{V}$ & Rusavskia elegans & no substrates for lichens & Rusavskia elegans & Rusavskia elegans \\
\hline
\end{tabular}

Zone II in the cities is characterised by the presence of taxa of very resistant epiphytic lichens, mainly with crustose thallus (Table 5). These epiphytes are found on the bark of trees in numerous places, reaching significant coverage. In Kraków and in the Niepołomicka Forest (KIsZKA 1977), in Toruń (ADAMSKA 2014) foliose thalli - Physcia adscendens, P. dubia, Phaeophyscia orbicularis, Physconia grisea and Polycauliona polycarpa, Xanthoria parietina were recorded in this zone. Rock lichens, such as Candelariella aurella, Lecanora albescens, L. dispersa are frequent in Kraków and Torun and form diverse multi-species groups. In many cities in shaded and damp places at the base of the pillars thalli of Flavoplaca citrina are found (Table 6).

In zone III on the bark of trees resistant epiphytes dominate occupying large areas. Foliose lichens, as Phaeophyscia orbicularis, Physcia adscendens, P. dubia, Xanthoria parietina were recorded as indicator species. There are single, usually small and degenerate thalli of Hypogymnia physodes, Parmelia sulcata (KIsZKA 1977, Matwiejuk 2007, Adamska 2014). Kiszka (1977) recorded a single stand of Evernia prunastri, Flavoparmelia caperata in this zone and in forest communities in the Niepolomicka Forest single thalli of Arthonia ruana, Parmeliopsis ambigua, Tuckermanopsis sepincola. In the inner zone of the limited vegetation concrete pillars are colonized mainly by placodioic thallus: Calogaya decipiens, C. pusilla, Lecanora muralis (Table 6).

In zone IV, the most resistant species significantly reduce their coverage. On concrete structures dominate foliose fronds of Phaeophyscia nigricans, Physcia adscendens, P. caesia, P. dubia, Xanthoria parietina. There are numerous foliose epiphytic lichens of Hypogymnia physodes, Melanohalea exasperatula, Parmelia sulcata. Locally, this zone reported fruticose thallus of Ramalina farinacea, R. pollinaria (KIsZKa 1977, Bielec 2011, AdamsKa 2014), Pseudevernia furfuracea (ADAmsKa 2014).

In zone $\mathrm{V}$ in cities foliose lichens occupy large areas, there are increasing numbers of fruticose lichens. Indicator species of zone $\mathrm{V}$ are Evernia prunastri, $R a-$ malina fastigiata, $R$. fraxinea. In some cities these are also species of genus Usnea: $U$. dasypoga, $U$. hirta, $U$. subfloridana (KIsZKa 1977, MatwiejUK 2007, AdAMSKA 2014). In zone V, in the Niepołomicka Forest KIszKA (1977) reported rare and endangered species Cetrelia cetrarioides, Evernia mesomorpha (Table 5). An indicator epilithic species in many cities is Rusavskia elegans (Table 6). At the positions described as zone $\mathrm{V}$ in some cities indicator species occur on individual trees, often in the form of a single thallus (MatwiejuK 2007, ADAMSKA 2014).

The lichenoindication study in Łomża confirmed the usefulness of lichens as bioindicators, as evidenced by the zonal distribution of biotest lichens. Lichenoindication zones in Łomża show that the state of the environment of the test area located near the Łomża Landscape Park of the Narew Valley is in good condition.

\section{ACKNOWLEDGEMENTS}

The authors would like to thank the Reviewers for insightful and kind attention. The paper has been financially supported by the Polish Ministry of Science and Higher Education through statutory research

\section{REFERENCES}

AdAmska E. (2014): Biota porostów Torunia na tle warunków siedliskowych miasta. Wydawnictwo Naukowe Uniwersytetu Mikołaja Kopernika, Toruń.

Arup U., Sandler Berlin E. (2011): A taxonomic study of Melanelixia fuliginosa in Europe. Lichenologist 43: 89-97.

Arup U., SøChting U., FrödÉn P. (2013): A new taxonomy of the family Teloschistaceae. Nordic Journal of Botany 31, 1: 16-83.

Bielec D. (2011): Lichenoindykacja Bielska-Białej syntetyczne strefy porostowe. Nauka Przyroda Technologie 5, 4\# 52.

Blanco O., Crespo A., Divakar P.K., Esslinger T.L., Hawksworth D.L., Lumbsch H.T. (2004): Melane- 
lixia and Melanohalea, two new genera segregated from Melanelia (Parmeliaceae) based on molecular and morphological data. Mycological Research 108(8): 873-884.

Војко A. (2007): Porosty wracają do miast. Zielona Planeta 1(70): 7-10.

BRODO I.M. (1961): Transplant experiments with corticolous lichens using a new technique. Ecology 42: 838-841.

BylińsKa E., SEAWARd M.R.D. (1993): Zmiany w zbiorowiskach porostów epifitycznych w Karpaczu pod wpływem skażeń chemicznych powietrza atmosferycznego. In: J. Sarosiek (ed.). Geoekologiczne problemy Karkonoszy. Część 2. Ekologia roślin i zwierząt. Wyd. Uniwersytetu Wrocławskiego, Wrocław: 159-165.

CiEślí́ski S. (1974): Flora epifityczna porostów miasta Radom. Biuletyn Kwartalny Radomskiego Towarzystwa Naukowego 11(3/4): 169-189.

CzyżEwsKa K. (2003a): Wprowadzenie. In: K. Czyżewska (ed.). Zagrożenie porostów w Polsce. Monographiae Botanicae 91: 5-11.

CzyżEWSKA K. (2003b): Ocena zagrożenia bioty porostów Polski. In: K. Czyżewska (ed.). Zagrożenie porostów w Polsce. Monographiae Botanicae 91: 241-249.

Diederich P., Ertz D., Stapper N., Sérusiaux E., Van Den Broeck D., Van Den Boom P., Ries C. (2015): The lichens and lichenicolous fungi of Belgium, Luxembourg and northern France. URL: http:// www.lichenology.info (access: 20.09.2015).

FABISZEwSKi J., Brej T., BieleCKI K. (1983): Plant indication examinations on environmental influence of copper smelter. Prace Wrocławskiego Towarzystwa Naukowego, Seria B 207: 1-100.

FAŁTYNOWICZ W. (1995): Wykorzystanie porostów do oceny zanieczyszczenia powietrza. Zasady, metody, klucze do oznaczania wybranych gatunków. Centrum Edukacji Ekologicznej Wsi, Krosno.

FAŁTYNowicz W. (2001): Ocena stopnia zanieczyszczenia powietrza w Starogardzie Gdańskim przy wykorzystaniu porostów jako wskaźników biologicznych. Prace Geograficzne 179: 187-195.

Fattynowicz W., Izydorek I., Budzbon E. (1991): The lichen flora as bioindicator of air pollution of Gdansk, Sopot and Gdynia. Monographiae Botanicae 73: 1-53.

FerRy B.W., Coppins B.J. (1979): Lichen transplant experiments and air pollution studies. Lichenologist 11(1): 63-73.

GrIes C. (1996): Lichens as indicators of air pollution. In: T.H. Nash III (ed.). Lichen biology. Cambridge University Press, Cambridge: 240-255.

GUS - Główny Urząd Statystyczny (2014). Ludność według płci i miast. http://stat.gov.pl/ obszary-tematyczne/ludnosc/ludnosc/ludnoscstan-i-struktura-ludnosci-oraz-ruch-naturalny- w-przekroju-terytorialnym-stan-w-dniu-31-xii2014-r-,6,17.html (access: 28.10.2015).

Hawksworth D.L., Rose F. (1970): Qualitative scale for estimating sulphur dioxide air pollution in England and Wales using epiphytic lichens. Nature 227: 145-148.

HoNEgGer R. (1998): The Lichen symbiosis - what is so spectacular about it? Lichenologist 30: 193212.

JASTRZĘBSKI W. (2004): Plan rozwoju lokalnego miasta Łomża na lata 2004-2006. Łomża. URL: http://www.lomza.pl/bip/zalaczniki/art/040616 104428.doc (access: 15.04.2016).

Kepel A. (1999): Porosty Poznania jako wskaźniki zanieczyszczenia atmosfery. $\mathrm{PhD}$ thesis. Typescript. Zakład Taksonomii Roślin, Uniwersytet im. Adama Mickiewicza w Poznaniu.

KIsZKA J. (1977): Wpływ emisji miejskich i przemysłowych na florę porostów (Lichenes) Krakowa i Puszczy Niepołomickiej. Prace Monograficzne Wyższej Szkoły Pedagogicznej w Krakowie 19: $1-137$.

KiszkA J. (1990): Lichenoindykacja obszaru województwa krakowskiego. Studia Ośrodka Dokumentacji Fizjograficznej 18: 201-212.

KiszKA J. (1991): Kumulacja siarki w plechach Hypogymnia physodes i korze forofitów na torfowiskach wysokich przy Bieszczadzkim Parku Narodowym. In: H. Lach (ed.). Biologiczne mechanizmy procesów adaptacyjnych. Wydawnictwo Naukowe Wyższej Szkoły Pedagogicznej, Kraków: 72-73.

KIsZKA J. (1999): Porosty (Lichenes) oraz warunki bioekologiczne Przemyśla. Arboretum Bolestraszyce 6: 1-86.

KisZKa J., KościelniaK R. (1996): Porosty miasta Krakowa oraz waloryzacja ich warunków bioekologicznych. Studia Ośrodka Dokumentacji Fizjograficznej 24: 21-72.

KŁos A. (2007): Porosty - biowskaźniki i biomonitory zanieczyszczenia środowiska. Chemia, Dydaktyka, Ekologia, Metrologia 12, 1-2: 61-77.

KondRACKI J. (2011): Geografia regionalna Polski. Wydawnictwo Naukowe PWN, Warszawa.

Kubiak D. (2004): Porosty Olsztyna na tle antropogenicznych przekształceń środowiska. $\mathrm{PhD}$ thesis. Typescript. Uniwersytet Warmińsko-Mazurski, Olsztyn.

Kuziel S., Halicz B. (1979): Występowanie porostów epifitycznych na obszarze Łodzi. Łódzkie Towarzystwo Naukowe. Sprawozdania z Czynności i Posiedzeń Naukowych 33, 3: 1-8.

LIPNICKI L. (1984): Porosty miasta Drezdenka i najbliższej okolicy. Fragmenta Floristica et Geobotanica 28, 2: 221-239.

ŁUBEK A. (2010): Ocena stanu środowiska przyrodniczego Kielc na podstawie bioty porostów epifitycznych. Fragmenta Floristica et Geobotanica Polonica 17, 1: 149-163. 
MARSKA B. (1979): Z badań nad porostami miasta Szczecina. Zeszyty Naukowe Akademii Rolniczej w Szczecinie. Rolnictwo 22 - Seria Przyrodnicza 77: 205-215.

Matuszkiewicz J.M. (2008): Geobotanical regionalization of Poland. Instytut Geografii i Przestrzennego Zagospodarowania PAN, Warszawa.

Matwiejuk A. (2007): Porosty Białegostoku jako wskaźniki zanieczyszczenia atmosfery. Wydawnictwo Ekonomia i Środowisko, Białystok: 1-102.

Matwiejuk A. (2014): Lichens of Sokółka (Podlasie, NE Poland) as indicators of the state of air pollution. Ochrona Środowiska i Zasobów Naturalnych 25, 2(60): 1-4.

Matwiejuk A., Korobkiewicz K. (2012a): Stan badań bioty porostów w miastach Polski. Ochrona Środowiska i Zasobów Naturalnych 51: 85-105.

Matwiejuk A., Korobiewicz K. (2012b): Porosty jako wskaźniki stanu zanieczyszczenia powietrza na terenie Narwi (Podlasie, Północno-Wschodnia Polska). Ochrona Środowiska i Zasobów Naturalnych 52: 113-122.

Miszalski Z., Niewiadomska E. (1993): Comparison of sulphite oxidation mechanisms in three lichen species. New Phytologist 123: 345-349.

NASH T.H., III (1996): Introduction. In: T.H. Nash III (ed.). Lichen biology. Cambridge University Press, Cambridge 1: 1-8.

Nordin A., Savič S., Tibell L. (2010): Phylogeny and taxonomy of Aspicilia and Megasporaceae. Mycologia 102, 6: 1339-1349.

NYLANDER W. (1866): Les lichens du Jardin du Luxembourg. Bulletin de la Société Botanique de France 13: 364-372.

PIšut I., Lackovičova A. (1991): Flechtenindikation im Gebiet von Bratislava (S. W. Slowakei). Kolloquium: Bioindikation ein Wirksames Instrument der Umweltkontrolle. Wien, 24-26 September 1991. VDI Berichte 901: 134-142.

Purvis W. (2000): Lichens. Natural History Museum, London.

PustelniaK L. (1991): Application of the transplantation method in studies on the influence of the ur- ban environment upon the vitality of Hypogymnia physodes (L.) Nyl. thalli. Zeszyty Naukowe Uniwersytetu Jagielońskiego, Prace Botaniczne 22: 193-201.

SEAWARD M.R.D. (1973): Lichen ecology of the Scunthorpe heathlands. I. Mineral accumulation. Lichenologist 5: 423-433.

ŚLIWA L. (2000): Lichenoindykcja zmian środowiska naturalnego Beskidu Sądeckiego. Ochrona Przyrody 57: 41-49.

Toвorowicz K. (1976): Porosty miasta Kielc i najbliższej okolicy. Fragmenta Floristica Geobotanica 22, 4: 575-603.

WilkoŃ-Michalska J., Glazik N., KalińsKa A. (1988): Porosty miasta Torunia. Acta Universitatis Nicolai Copernici, Nauki Matematyczno-Przyrodnicze 63, Biologia 29: 209-253.

WIOŚ - Wojewódzki Inspektorat Ochrony Środowiska w Białymstoku Delegatura w Łomży. (2015). Informacja Podlaskiego Wojewódzkiego Inspektora Ochrony Środowiska w Białymstoku o stanie środowiska na terenie Łomży w 2014 roku. https:// pl.wikipedia.org/wiki/\%C5\%81 om\%C5\%BCa (access: 30.10.2015).

WiRTH V. (1995): Die Flechten Baden-Württembergs. Bd. 1-2. Ulmer, Stuttgart.

ZAŁUPKA M. (2008): Plan ochrony powietrza dla Miasta Łomża, 1-65. http://www.lomza.pl/bip/zalaczniki/art/130321091612.pdf (access: 3.04.2016).

ZimnY H., KucińsKA K. (1974): Porosty Warszawy jako biowskaźniki zaburzeń środowiska miejskiego. Przegląd Informacyjny - Zieleń Miejska 10/1. Instytut Gospodarki Komunalnej, Warszawa: 13-22.

ZURZYCKI J. (1950): Badania nad nadrzewnymi porostami Krakowa i okolicy. Materiały do Fizjografii Kraju 24, Kraków: 1-30.

For citation: Matwiejuk A., Chojnowska P. (2016): Lichens as indicators of air pollution in Łomża. Steciana 20(2): 63-72. doi: 10.12657/steciana. 020.008 